\title{
TO THE RESCUE: LIABILITY IN NEGLIGENCE FOR THIRD PARTY CRIMINAL ACTS IN THE UNITED STATES AND AUSTRALIA
}

\author{
Stephen Tuck
}

\section{INTRODUCTION}

The lawyer's maxim de minimis non curat lex (the law does not concern itself with trifles) has two problems. First, it is a cliché. Second, it is inaccurate. The case of Donoghue v. Stevenson, which unbottled the jurisprudential genie of the tort of negligence for much of the common law world, arose from a minor incident in a Scottish café. ${ }^{1}$ Despite this unremarkable origin, one might perhaps say that nearly all subsequent jurisprudence in the law of negligence has attempted to identify the limits of the doctrines laid down in that case. ${ }^{2}$ The intricacy of this search for the limits is generated by the tension between a duty to avoid negligence or foreseeable harm and the "non-intervention principle" that one person is generally not obliged to take steps to protect another person. ${ }^{3}$

The tension between the duty and the non-intervention principle is raised in a marked form by claims in negligence arising out of criminal acts committed by third parties. In the common law of both the United States and Australia, the initial premise can be summarized by stating that one party is not obliged to protect another from a third party's criminal act. ${ }^{4}$ However, in both countries, the law has developed to reflect the following jurisprudential norm: liability attaches where a defendant has allowed a plaintiff to suffer harm through a criminal act when the defendant (a) can reasonably foresee that harm would occur and (b) is capable of acting to prevent it. This principle is hereinafter called the "foreseeability/capacity analysis" in which the degree of foreseeability is balanced against the level of capacity to act in assessing the likelihood of liability being found.

Australia and the United States represent largely unconnected outgrowths. of the same philosophical tree. ${ }^{5}$ Such similarities are validated

1. Justin Fleming, Barbarism to Verdict 158-59 (Angus \& Robertson 1994) (describing the incident as recorded in Donoghue v. Stevenson, [1932] A.C. 562 (H.L.) (appeal taken from Scot.)).

2. Cf. Modbury Triangle Shopping Crt. Pty. Ltd. v Anzil [2000] 205 CLR 254, 274-75 (Austl.) (Kirby, J.).

3. See McKinnon v Burtatowski (Sup. Ct. Vic) [1969] VR 899, 903-04 (Austl.), available at http://www.austlii.edu.au/au/cases/vic/VicRp/1969/111.html (last visited Apr. 14, 2013).

4. Nivens v. 7-11 Hoagy's Corner, 943 P.2d. 286, 290 (Wash. 1997); Smith v Leurs [1945] 70 CLR 256, 262 (Austl.) (Dixion, J.).

5. Hugh BiCHENO, Rebels and RedCOATS xxxiii (Harper Collins 2003) (see diagram of related traditions). 
by the American and English courts drawing insight from each other during the development of the law of negligence; although this is perhaps more controversial today. ${ }^{6}$ As Lord Atkin commented in Donoghue v. Stevenson, "It is always a satisfaction to an English lawyer to be able to test his application of fundamental principles of the common law by the development of the same doctrines by the lawyers of the Courts of the United States." In the landmark American decision of MacPherson $v$. Buick Motor Company, both the majority and dissenting opinions saw merit in reviewing English case law ${ }^{8}$ in a fashion similar to the approach long taken by Australian courts. ${ }^{9}$ Therefore, a comparative analysis of their common law should shed light on the necessary and natural developments of the common law negligence for criminal acts of third parties.

\section{Claims against PRivate DefEndants}

\section{A. Modbury Triangle Shopping Centre Pty. Ltd. v Anzil and What Happened Next: The Australian Experience}

Claims against private defendants for negligently failing to prevent criminal acts of third parties tend to be brought against the owners or managers of the premises where or arising out of which offenses have occurred. In Australian law these claims represent an outgrowth of the law related to occupiers' liability. The classic cases on occupiers' liability are both appeals to the Privy Council from the High Court of Australia. In

6. See Justice Scalia's robust defense of American jurisprudential independence: "The Court should either profess its willingness to reconsider [rules relating to criminal evidence, disestablishmentarianism, abortion and double jeopardy] in light of the views of foreigners, or else it should cease putting forth foreigners' views as part of the reasoned basis of its decisions. To invoke alien law when it agrees with one's own thinking, and ignore it otherwise, is not reasoned decision-making, but sophistry.". Roper v. Simmons, 543 U.S. 551, 627 (2005) (Scalia, J. dissenting) (Rehnquist, CJ. and Thomas, J. join the dissent). His Honor wrote in dissent, but one notes the majority made little attempt to disagree: "The opinion of the world community, while not controlling our outcome, does provide respected and significant confirmation for our own conclusions.". Id. at 578 (Kennedy, J.) (Stevens, Souter, Ginsburg and Breyer, JJ. concurring).

7. Donoghue v. Stevenson [1932] A.C. 562, 598 (H.L.) 598 (appeal taken from Scot.)., available at http://www.bailii.org/uk/cases/UKHL/1932/100.html (last visited Apr. 14, 2013).

8. MacPherson v. Buick, 217 N.Y. 382, $392-93$ (N.Y. 1916) (Cardozo, J.); see also id. at 397 (Bartlett, CJ. dissenting).

9. For instance, one notes that within a year of Donoghue $v$ Stevenson being reported, it formed part of the arguments in Australia on compensation for sale of defective goods: Australian Knitting Mills Ltd v Grant [1933] 50 CLR 387, 409 (Austl.) (Starke, J.); id. at 412 (Dixon, J.); id. at 440 (Evatt, J.). There is a powerful line of argument that Australian courts should continue to bear in mind the decisions of English and other foreign courts. See Cook $v$ Cook [1986] 162 CLR 376, 390 (Austl.) (Mason, Wilson, Deane and Dawson, JJ.); see also id. at 394 (Brennan, J.); see also Modbury Triangle [2000] 205 CLR 276 (Austl.) (Kirby, J.); see also Imbree v McNeilly [2008] 236 CLR 510, 549 (Austl.) (Kirby, J.). 
Rickards $v$ Lothian, an unknown person blocked a drain on a property of which the defendant was a lessee..$^{10}$ The unknown person then turned the tap on over the drain overnight that caused a flood, which damaged the plaintiff's goods. The Privy Council held that the law does not impose liability on an occupier of premises for damage caused by the wrongful act of a third party. ${ }^{11}$ This principle was clarified in the later case of Goldman $v$ Hargrave. ${ }^{12}$ In that case, a tree on the defendant's property caught on fire. He took some steps to control the fire but ultimately left it to burn itself out. Some days later, the fire flared up following a change in the weather thus causing it to spread from the defendant's to the plaintiff's property, which caused significant damage. After the Supreme Court of Western Australia and High Court of Australia dealt with the matter, it was placed before the Privy Council. Their Lordships found that while (consistently with Rickards $v$. Lothian) an occupier is not generally liable for a third party's wrongful act, there is a duty to remove a hazard to a person arising from one's premises where there is knowledge of the danger, the ability to foresee the consequences of not inspecting or removing it, and the ability to abate it. ${ }^{13}$

These concepts of knowledge, foreseeabililty, and capacity received a particularly precise restatement in the context of liability for criminal acts of third parties in the leading Australian case of Modbury Triangle Shopping Centre Pty. Ltd. v Anzil. ${ }^{14}$ This case took Australian common law closer to reflecting the foreseeability/capacity analysis discussed earlier. In this case, the employee of a video store tenant of a shopping center left the premises after dark one evening. Due to the Center management's failure to keep the lighting in the parking lot illuminated, he was assaulted and badly injured. The offenders were not located and the employee initiated proceedings against the shopping center. The matter was ultimately placed on appeal before the High Court of Australia. The Court found that, as a general rule, the existence of a risk of harm to a person lawfully on premises from criminal behavior was insufficient to impose a duty of care on the occupier of the premises in the absence of a special relationship between the parties. ${ }^{15}$ The leading judgment was delivered by Chief Justice Gleeson (with whom Justices Gaudron and Hayne agreed) ${ }^{16}$ who noted:

[T] two parties may mean that one has a duty to take

10. Rickards v. Lothian, [1913] A.C. 263 (P. C.) (appeal taken from Austl.).

11. Id.

12. See generally Goldman v. Hargrave, [1967] 1 A.C. 645 (P. C.) (appeal taken from Austl.).

13. $I d$.

14. See Modbury Triangle, 205 CLR at 267-68.

15. Id. at 267.

16. Id. at 270 (Gaudron, J.); id. at 288 (Hayne, J.). 
reasonable care to protect the other from the criminal behaviour of third parties, random and unpredictable as such behaviour may be. Such relationships may include those between employer and employee, school and pupil, or bailor and bailee. But, the general rule that there is no duty to prevent a third party from harming another is based in part upon a more fundamental principle, which is that the common law does not ordinarily impose liability for omissions. ${ }^{17}$ (Internal citations omitted).

Justice Gaudron made a similar assessment. Her Honor observed that:

There are situations in which there is a duty of care to warn or take other positive steps to protect another against harm from third parties. Usually, a duty of care of that kind arises because of special vulnerability, on the one hand, and on the other, special knowledge, the assumption of a responsibility or a combination of both. Those situations aside, however, the law is, and in my view should be, slow to impose a duty of care on a person with respect to the actions of third parties over whom he or she has no control. $^{18}$

The power to control third parties was also significant in the judgment of Justice Hayne who observed that:

If the appellant owed the first respondent a relevant duty of care, it was to take whatever steps were reasonable in all the circumstances to hinder or prevent any criminal conduct of third persons which injured the first respondent or any person lawfully on the premises. But the acts of those third parties resulted from the choices which they made. Moreover, they were choices which were .. . not necessarily dictated by reason or prudential considerations. It was, therefore, a duty to take reasonable steps to attempt to affect the conduct of persons whom it had no power to control. No such duty has been or should be recognized. . .In those cases where a duty to control the conduct of a third party has been held to exist, the party who owed the duty has had power to assert control over that third party. A gaoler may owe a prisoner a duty to take reasonable care to 
prevent assault by fellow prisoners. . . Similarly, a parent may be liable to another for the misconduct of a child because the parent is expected to be able to control the child. $^{19}$

However, Chief Justice Gleeson did offer a qualification, which has been critical to the subsequent development of the law in Australia:

The unpredictability of criminal behaviour is one of the reasons why, as a general rule, and in the absence of some special relationship, the law does not impose a duty to prevent harm to another from the criminal conduct of a third party, even if the risk of such harm is foreseeable. There may be circumstances in which, not only is there a foreseeable risk of harm from criminal conduct by a third party, but, in addition, the criminal conduct is attended by such a high degree of forseeability, and predictability, that it is possible to argue that the case would be taken out of the operation of the general principle and the law may impose a duty to take reasonable steps to prevent it. ${ }^{20}$

It must be conceded that Chief Justice Gleeson did tend to doubt that a duty could be created through these means:

It is unnecessary to express a concluded opinion as to whether foreseeability and predictability of criminal behaviour could ever exist in such a degree that, even in the absence of some special relationship, Australian law would impose a duty to take reasonable care to prevent harm to another from such behaviour .... It suffices to say two things: first, as a matter of principle, such a result would be difficult to reconcile with the general rule that one person has no legal duty to rescue another; and secondly, as a matter of fact, the present case is nowhere near the situation postulated. ${ }^{21}$

Justice Hayne also left open for later consideration the approach to take in situations where it involved an occupier of land having a high degree of certainty that harm would follow from a lack of action. ${ }^{22}$ Justice Callinan

19. Id. at 291-92 (footnotes omitted).

20. Id. at 267.

21. Id. at 268 (footnote omitted).

22. Id. at 293-94. 
similarly concluded that in this case, the appellant's duty to Mr. Anzil did not extend to keeping the lights on. ${ }^{23}$ However, he also stated:

That does not mean that there can never be a duty, whether dischargeable by turning lights on, or otherwise to take precautions to prevent or reduce the chances of criminally inflicted injury or loss by third parties. However, ... for such a duty to arise, there must be something special in the circumstances, or the nature of the relationship between the plaintiff and the defendant. ${ }^{24}$

Despite Chief Justice Gleeson's doubts as to the possible existence of a duty to prevent harm regardless of the relationship between the parties, the ruling in Modbury Triangle fits securely within the earlier developed law. The decision accepts in Modbury as a general rule the absence of a duty of care identified in Rickards. ${ }^{25}$ However, it is difficult not to see that the high likelihood of criminal behavior, which Chief Justice Gleeson and Justices Gaudron, Hayne and (seemingly) Callinan felt might conceivably give rise to a duty as conceptually anything other than the knowledge of the hazard giving rise to a duty in Goldman. This duty, however, would only operate where the occupier of land had the capacity to prevent the harm. As Justice Gaudron observed, "I agree . . . with the remarks of Hayne J, particularly his Honour's emphasis on the significance of control over third parties before the law imposes a duty of care to prevent foreseeable damage from their actions." ${ }^{26}$ Therefore, this case represents a rendering down of the requirements for identifying a duty of care to foreseeability of harm and the capacity to prevent it.

The powerful dissent of Justice Kirby in Modbury Triangle seems to accept an underlying foreseeability/capacity analysis, which indicates that the Court was indeed drawing from a single set of legal concepts in considering the existence of a duty. His Honor pointed out that:

Proving a breach of a duty of care of a given scope will usually depend, in a case such as the present, on whether the landlord had actual or constructive knowledge of risks faced by the particular entrant. Whilst entrants as a class, and particular entrants, cannot impose liability simply by giving notice to the landlord of some real or imagined danger, the fact of notice is at least an answer to a

23. Id. at 302

24. Id.

25. Modbury Triangle, 205 CLR at 265.

26. Id. at 270 (emphasis added). 
suggestion that subsequent damage and loss was unforeseeable. The more notice that is given, and the more often, the more likely will it be that legal liability will be imposed for the failure to respond to such notice where doing so would have been simple and reasonable in the circumstances and protective of the claimant. ${ }^{27}$

Justice Kirby found that a duty is created where there is sufficient foreseeability and where the occupier was capable of responding to the threat perceived. ${ }^{28}$ It is difficult to perceive a difference between this analysis and the circumstance where a duty of care might perhaps exist as identified by the majority. Based on the evidence, Justice Kirby duly proceeded to find a duty of care existed in leaving the lights on to protect Mr. Anzil from criminal harm. ${ }^{29}$

Notwithstanding Chief Justice Gleeson's doubts about whether criminal behavior could be so probable that a duty of care could be found, lower courts have since directed their energies to considering when the necessary certainty of a criminal offence might exist in conjunction with the necessary level of control. ${ }^{30}$ In Ashrafi Persian Trading Co Pty. Ltd. $v$ Ashrafinia, a young woman was struck on the head by an iron bar that was sticking out from a small gap in the window of a motel where she was staying. ${ }^{31}$ Justice (of Appeal) Heydon (as he then was) delivered the lead judgment, with whom President (of the Court of Appeal) Mason and Justice (of Appeal) Handley agreed. ${ }^{32}$ His Honor noted that in the following special relationships, a person has a duty to protect another from a third party's criminal act and that such duty to protect these relationships was related to the existence of control: employers to employees, schools to pupils, bailees

27. Id. at $283-84$.

28. Id.

29. Id. at 285-86.

30. The legitimacy of such consideration has been questioned: "When judges of the High Court decide to leave matters open for consideration in future cases, they do so because of a consciousness that to create an exception to the principle precluding recovery for the criminal acts of third parties is to take an important step not to be embarked on without careful consideration in a particular case requiring the step. The making of significant changes in the law by taking steps of that kind is, if not beyond the competence of intermediate appellate courts, something not to be done lightly. It is better for these matters to be left open for the consideration of the High Court." Proprietors of Strata Plan $17226 \mathrm{v}$ Drakulic [2002] 55 NSWLR 659, 684 (Heydon, JA.) (Austl.). With the greatest of respect to his Honor, such an approach is an abdication of judicial responsibility: "The function of the court is to decide the case before it, even though the decision may require the extension or adaptation of a principle or in some cases the creation of new law to meet the justice of the case." McLoughlin v. O'Brian [1983] 1 A.C. 410,430 (H.L.) 430 (Lord Scarman).

31. Ashrafi Persian Trading Co Pty. Ltd. v Ashrafinia [2002] Aust Torts Report qף81636 (Austl.).

32. Id. at 68.315 . 
to bailors, parents to third parties for acts of their children, and sometimes goalers to prisoners and civilians. ${ }^{33} \mathrm{He}$ then noted that:

The category of "special circumstances" or "a special relationship" can obviously overlap with cases where liability is found because of "a high degree of certainty that harm will follow from lack of action". Frequently recurring crimes might establish a high degree of certainty that harm will follow, and also evidence special circumstances .... ${ }^{34}$

The plaintiff had argued that a duty of care was owed due to the high foreseeability of the conduct, which injured her. ${ }^{35}$ The motel's history included a "pattern of criminal conduct involving attempted or actual thefts and burglaries." ${ }^{36}$ His Honor responded that:

Whether or not there was a reasonably foreseeable risk of injury, or even a reasonably foreseeable risk of the injury which in fact happened, the risk was not such as to answer the description employed by Hayne J ('a high degree of certainty that harm will follow from lack of action') or Gleeson CJ ('a high degree of foreseeability, and predictability'). ${ }^{37}$

His Honor further concluded that had a duty existed, it was discharged by having provided a lock on the door, which the plaintiff could have used if she wished. ${ }^{38}$ Special leave to appeal to the High Court of Australia was refused. ${ }^{39}$

Another ruling sheds further light on the norm reflected in earlier case law. The finding in Brown v Drummoyne Sports Club Ltd. not only reflects the foreseeability/capacity analysis, but confirms that it fits within the principles of the common law established in Rickards and Goldman. ${ }^{40} \mathrm{~A}$ test for such consistency is that, if the harm is foreseeable, there would be a duty to prevent it even in the absence of a long history of criminal

33. Id. at 68,335 .

34. Id. at 68,336 .

35. Id. at 68,322 (Heydon, JA.).

36. Id.

37. Id. at 68,337 . The plaintiff's alternative argument that she was in a special relationship with the defendant was also rejected. $I d$. at 68,339 .

38. Id. at 68,339 .

39. Ashrafinia v Ashrafi Persian Trading Co. Pty Ltd. (Unreported, High Ct. of Austl., 19 Apr. 2002) (Gleeson, CJ. and McHugh, J.).

40. Brown v Drummoyne Sports Club Ltd. [2007] 5 DCLR (NSW) 98 (NSW Dist. Ct.). Cf. Rickards v. Lothian [1913] A.C. 263 (P.C.) (appeal taken from Austl.); Goldman v. Hargrave, [1967] 1 A.C. 645 (P.C.) (appeal taken from Austl.). 
offending, if the consequences of the harm would be severe or the means of preventing it are straightforward. Such was the finding in Brown. ${ }^{41}$ In this case, three prior offenses were sufficient to establish the necessary risk of injury where the steps to prevent such injury were not excessively onerous. ${ }^{42}$ District Court Judge Phegan defined the "Modbury rule" as the following: an occupier has no duty of care to take steps to protect another (even if that other is lawfully on the premises) from injury caused by the criminal conduct of people over whom the occupier lacks immediate control or has no other reason in law for having any control arising from a special relationship between the parties. ${ }^{43} \mathrm{He}$ stated that "for an exception to the Modbury rule to be made, there must be a high degree of risk and that the imposition of a duty must not be unduly onerous on the defendant in the face of such a risk. ${ }^{, 44}$ In the event, his Honor found:

[t]hat there was a breach of duty of care on the part of the defendant club in failing to secure the entrance doors between $8 \mathrm{pm}$ and $9 \mathrm{pm}$ on the night on which the plaintiff was injured. Such a precaution ... would have significantly reduced the risk of injury to the plaintiff.. . The finding of a breach of duty is also reinforced by the history which I have recorded earlier in the judgment. This was not an incident which occurred in isolation. It is not a case driven entirely with the benefit of hindsight. It is a case in which forced entry occurred within two months of a sequence of other events which, combined with the general knowledge which should have been available to the club of the rise in robberies of premises such as those occupied by the defendant, should have galvanized the defendant's mind to consider additional security measures, particularly measures which would have cost nothing. ${ }^{45}$

Therefore, it can be inferred that a duty will likely exist when the remedial action is amply within the defendant's capacity and the level of foreseeability is low.

Justice (of Appeal) Heydon made a different assessment in the

41. Brown, supra note 40, ๆ 81.

42. See infra note 45.

43. Brown, supra note $40,179$.

44. Id. ๆ 81.

45. Id. If 101-102. On the relevance of robberies in the area. $C f$. the California Court of Appeal's observation that "in any analysis of foreseeability, the emphasis must be on the specific, rather than more general, facts of which a defendant was or should have been aware. That is, there is little utility in evidence that, for example, the Pacific Beach area of San Diego is a "high crime area."' Pamela W v. Millsom, 25 Cal. App. 4th 950, 957 (1994). 
leading judgment in Proprietors of Strata Plan $17226 v$ Drakulic. ${ }^{46}$ His Honor doubted the significance of capacity as a basis for imposing a duty:

The question is whether there is a duty to provide a locked door. The proffered answer is affirmative, because there is control. But whence does control come? From the ability to provide a locked door. It cannot be right to infer a duty to do something merely from the fact that it is possible to do it. $^{47}$

He also tended to doubt highly predictable crime of the sort imagined by Chief Justice Gleeson and Justice Hayne in Modbury Triangle v Anzil could give rise to a duty of care. ${ }^{48} \mathrm{He}$ did not concede in any event that the likelihood of criminal offending was sufficiently high in this matter to establish a duty. ${ }^{49}$ Justice Heydon noted that there had been litigation in the United States against landlords and similar persons by tenants in relation to criminal injuries in which the test for a duty of care was reasonable foreseeability, which may arise from knowledge of prior crimes even if they were different from the crime sued on. ${ }^{50}$ He then reviewed the High Court's analysis of the American cases and concluded that it was not open to the Court of Appeal to apply "even if it considered them sound in principle." With the utmost respect to His Honor, his analysis is excessively restrictive. There is a viable argument that the reasonable foreseeability test in the American cases is not too far short of the level of foreseeability that Modbury Triangle $v$ Anzil requires. His Honor had observed that "[t]hat which is 'foreseeable' is not to be confused with that which is 'reasonably foreseeable' . ... Whether or not the test of reasonable foreseeability is a demanding test, it is a test with some content. ${ }^{\text {"52 }}$ Moreover, in identifying a duty of care the question of foreseeability cannot be looked at in isolation from that of capacity. As Justice Heath observed "it is both 'naïve' and 'absurd and dangerous' to assert existence of a prima facie duty of care whenever harm is reasonably foreseeable. ${ }^{~} 53$ In assessing what may convert reasonable foreseeability into a duty of care, it is proper to consider what would be a reasonable response to that foreseeable harm and what capacity

46. See Proprietors of Strata Plan $17226 v$ Drakulic [2002] 55 NSWLR 659 (Austl.).

47. Id. 177 . (emphasis added).

48. Id. $\$ 92$.

49. Id. $\$ 93$.

50. Id. ๆ 127.

51. Id.

52. Ashrafi Persian Trading Co. Pty. Ltd. v Ashrafinia [2002] Aust Torts Report ๆף 81636, 68, 317 (Austl.).

53. Hobson v Att'y Gen. [2005] 2 NZLR 220, 237 (HC). 
the defendant was in. ${ }^{54}$ This is consistent with the other cases discussed in this Article and with the approaches in Modbury Triangle v Anzil. One must therefore respectfully submit that His Honor's doubts are out of step with the trend of jurisprudence.

If the posited foreseeability/capacity analysis does indeed underpin the common law in cases of civil liability for third party criminal acts, it should be capable of explaining the imposition of a duty to prevent criminal offences in cases of special relationships. It would also be expected that eventually the concepts of duties arising from a special relationship and duties arising from highly-foreseeable offenses would draw more closely together or merge (this would itself arguably point the way towards liability by private citizens not being tied to occupation of premises.) Such a case arose in Club Italia (Geelong) Inc. $v$ Ritchie. ${ }^{55}$ In this matter the plaintiff, a police officer, was called to a disturbance at a social club. The Club allowed a violent situation to develop and failed to eject the troublemaker (Holton) who subsequently attacked and caused significant injury to the plaintiff. The Court noted that the club operators realized that they may attract troublemakers and that they should take steps to deal with the danger of violence or disorder. ${ }^{56}$ If someone becomes drunk or criminally disorderly on the premises, then it is the venue operators who have invited him to be there and created the environment where the activity has occurred. ${ }^{57}$ They are then under a statutory duty to remove the drunk and disorderly person and to maintain order on the premises. ${ }^{58}$ The Court further stated that:

[e]ach of the majority judgments in Modbury makes it clear that the basis of the 'special relationship' exception is . . . the existence of 'control'. Where the defendant is in a position to control the offender, a special relationship may be held to exist. The club was in a position to control Holton; a special relationship, and prima facie a relevant duty of care, existed. ${ }^{59}$

Interestingly, the Court did not see the need to consider whether a duty was created by reason of the degree of foreseeability and predictability of criminal conduct. After the Court found a duty existed, it agreed that the club had breached it and proceeded to assess damages. ${ }^{60}$

54. See Caledonian Collieries Ltd v Speirs [1957] 97 CLR 202, 221-225 (Dixon, CJ., McTiernan, Kitto and Taylor, JJ. (Austl.).

55. Club Italia (Geelong) Inc. v Ritchie [2001] 3 VR 437 (Vic Ct. App.) (Austl.).

56. Id. $\uparrow 36$.

57. $I d$.

58. $I d$.

59. Id. ๆ 45 .

60. Id. ๆा 51-54. 
The Court of Appeal in the Club Italia ruling based the special relationship on the control of the offender, which must logically be coterminous with capacity. A range of factors is used to determine the action that is required to discharge the duty created by the special relationship. ${ }^{61}$ Preventing a crime is more likely to be part of the duty as the likelihood of a criminal offense increases. ${ }^{62}$ It is not easy, then, to see how the creation of the duty of care in Club Italia differed from that arising from the exception to the Modbury principle discussed above.

Consistently, the Club Italia ruling also seems to extend the duty to prevent harm by making the capacity to control an offender the basis of a special relationship between an injured plaintiff and a defendant thus creating a duty of care to prevent reasonably foreseeable harm arising from inaction. ${ }^{63}$ Australian law recognizes a right to use force to defend a stranger. After a magisterial survey of the law, Justice Crawford stated:

I take the law to be that a person is entitled to use force to prevent a stranger from being assaulted if he has reasonable grounds for believing that an assault upon that stranger is about to take place. In considering what force may be used, I hold that it must be reasonably proportioned to the degree of injury to be expected from the assault upon the stranger . . . . The time factor must also be considered and if it is possible gently to restrain the would-be assailant then this should be the manner of dealing with him. ${ }^{64}$

It would follow that a person with suitable skill and training may find themselves both entitled in law and able in fact to control an offender and therefore in a special relationship with a person in danger where he or she can foresee injury to that person from a lack of action. One could infer that if an elderly person was being menaced in a suburban street by a young delinquent as part of a robbery, ${ }^{65}$ and a reasonably fit twenty-year old citizen with a hobby in recreational martial arts witness this, the rule in Goss would permit the person to intervene to aid the victim as he has the likely capacity to do so. ${ }^{66}$ Moreover, failure by them to do so, followed by

61. Richards v Victoria [1969] VR 136, 142 (Sup. Ct. Vic) (Austl.) (Full Court).

62. See Doe v. Holy, 557 F.3d 1066, 1093-94 (9th Cir. 2009) (Beron, J., dissenting).

63. Id.

64. Goss v Nicholas [1960] Tas SR 133, 144 (Sup. Ct. Tas) (Austl.); Crimes Act 1958 (Vic.), s 462A (Austl.).

65. I have in mind a number of compensation claims I have encountered in my practice that involved this basic scenario.

66. See generally Rozsa v Samuels [1969] SASR 205, 210 (Sup. Ct. of S. Austl.) (presumably using the same degree of force as the victim themselves might use, including using all reasonable non-forceful means of warding off violence before applying force). 
injury to the hypothetical geriatric, could potentially be compensable in negligence if the said negligent person could be identified. Noting that both the "special relationship" and "Modbury exception" draw on the same foreseeability/capacity analysis, it follows that there is no necessary reason why a duty might not fall on one person to an unrelated third person where the danger is sufficiently high or the means of averting it sufficiently basic. The ramifications of this decision remain unexplored in Australian law; the only reported decision referring to Club Italia v. Ritchie is a 2002 decision of the New South Wales Court of Appeal in which the Court noted that the case dealt with as one involving a special relationship between the club and the plaintiff but did not explore the principles underlying the relationship. ${ }^{67}$

\section{B. The American Experience}

American law in this area draws from the same underlying foreseeability/capacity analysis. It is beyond this article's scope to analyze the law for each of the United States' many jurisdictions. However, it seems reasonable to consider certain declaratory cases for the fundamental jurisprudential norms.

American law seemingly has no a priori objection to finding liability for criminal acts of third parties. In Lillie $v$. Thompson, the plaintiff (a twenty-two year old woman) was required to the work night shift alone as a telegraph operator in a one-room building in an isolated area. ${ }^{68}$ The area was known to be frequented by "dangerous characters"; despite this, the building was neither well lit nor guarded or patrolled. ${ }^{69}$ The plaintiff was required to open the door to pass messages to other employees throughout the night, and there was no means for her to identify a person at the door without unlocking it. ${ }^{70}$ On the night at issue, a third party forced the door after it was opened and assaulted the plaintiff thus causing injuries. ${ }^{71}$ The Supreme Court of the United States held:

We are of the opinion that the allegations in the complaint, if supported by evidence, will warrant submission to a jury. Petitioner alleged in effect that respondent was aware of conditions which created a likelihood that a young woman performing the duties required of petitioner would suffer just such an injury as was in fact inflicted upon her. That the foreseeable danger was from intentional or criminal

67. Strata Plan 17226 v Drakulic [2002] 55 NSWLR 659, 692 ( $(114)$ (Ct. App. NSW) (Austl.).

68. Lillie v. Thompson, 332 U.S. 459 (1947).

69. Id.

70. Id. at 460 .

71. Id. 
misconduct is irrelevant; respondent nonetheless had a duty to make reasonable provision against it. Breach of that duty would be negligence, and we cannot say as a matter of law that petitioner's injury did not result at least in part from such negligence. ${ }^{72}$

There is no indication that the employment relationship (recognized in Australian law as a "special relationship" imposing a duty on the employer to prevent injuries caused by third parties ${ }^{73}$ ) was the controlling factor in a duty being imposed. ${ }^{74}$ Subsequent American case law appears to have accepted this principle as applying generally to the question of liability for injuries caused by the criminal acts of third parties. ${ }^{75}$

One of the leading cases in American law on this point is Ann M.v. Pacific Plaza Shopping Center. ${ }^{76}$ Similar to Anzil, this case concerned the employee of a tenant of a shopping center. In the morning of June 17, 1985, the plaintiff was the only employee on duty when a person entered the store and raped her. ${ }^{77}$ She alleged the center was negligent in failing to provide adequate security to protect her from harm. ${ }^{78}$ The California Supreme Court was clear:

It is now well established that California law requires landowners to maintain land in their possession and control in a reasonably safe condition. ... In the case of a landlord, this general duty of maintenance, which is owed to tenants and patrons, has been held to include the duty to take reasonable steps to secure common areas against [reasonably] foreseeable criminal acts of third parties that are likely to occur in the absence of such precautionary measures. ${ }^{79}$

The court said that the scope of the landlord's duty to protect against crime was determined in part by balancing the foreseeability of the harm against the burden of the duty to be imposed. ${ }^{80}$ In cases where the burden of

72. Id. at 461-62 (footnote omitted).

73. Ashrafi Persian Trading Co. Pty. Ltd. v Ashrafinia [2002] Aust Torts Report ๆf 81636 at 68,335 .

74. Lillie, 332 U.S. at 462.

75. See Modbury Triangle Shopping Ctr. Pty. Ltd. v Anzil [2000] 205 CLR 254, 278 (Austl.).

76. Ann M. v. Pacific Plaza Shopping Center, 863 P.2d 207 (Cal. 1993).

77. Id. at 210.

78. Id. at 211 .

79. Id. at 212 .

80. Id. 
preventing harm was significant, a high degree of foreseeability may be needed. Equally, less foreseeability may be required if the harm could be prevented by simple means. ${ }^{81}$

The court further held that for the duty of care to involve hiring private security guards, it would require a degree of foreseeability almost only demonstrable by prior similar incidents of violence on the landowner's premises. ${ }^{82}$ A subsequent case held that the burdensomeness of the remedial measures could be assessed against the capacity of the individual landlord. ${ }^{83}$ Hence, if a high degree of foreseeability was required to find a shopping center was obliged to hire security guards, a similarly high degree of foreseeability would be needed to find that either the individual landlord or condominium association had a duty of care to making rented premises essentially entry-proof. ${ }^{84}$ It can be observed that this line of analysis is also the position in Australian law post-Anzil and is evidently drawn from the same foreseeability/capacity analysis.

The Californian approach to the law is consistent with the law elsewhere. The Supreme Court of Georgia, for example, has laid down that:

The general rule regarding premises liability is that a landlord does not insure tenants' safety against third-party criminal attacks, and that any liability from such attacks must be predicated on a breach of duty to "exercise ordinary care in keeping the premises and approaches safe" ... A landlord's duty to exercise ordinary care to protect tenants against third-party criminal attacks extends only to foreseeable criminal acts. ${ }^{85}$

It seems entirely plausible to assume that "ordinary care" reflects the different levels of foreseeability and the burden such care would place on the landlord. This case required that the incident which causes the injury be substantially similar in type to the previous criminal activities occurring on or in the vicinity of the premises so that a reasonable person would take ordinary precautions to protect his or her tenants or customers against the risk. ${ }^{86}$ The Modbury Court took a very similar approach.

The foreseeability/capacity analysis allows us to explain American common law where duties to business invitees are concerned. One can note first that such a duty to prevent injuries from criminal offending exists. For example, in Borne v. Bourg, the plaintiff was blinded in one eye by an

\footnotetext{
81. Id. at 215 .

82. Id.

83. Pamela W. v. Millsom, 25 Cal. App. 4th 950, 959 (1994)

84. Id.

85. Sturbridge Partners Ltd. v. Walker, 482 S.E.2d 339, 340 (Ga. 1997).

86. Id. at 341 .
} 
offender in the course of a confrontation after a period of harassment of him by the offender. ${ }^{87}$ The bartender of the establishment had recognized that a confrontation was brewing and made a wholly inadequate (and unsuccessful) effort to call the police at a time when an intervention by them was possible. ${ }^{88}$ At the last moment he ordered the offender to leave the bar. ${ }^{89}$ The Court found that the bartender's failure to call police when one customer began harassing another who was ultimately injured in the confrontation was a breach of the bar's duty to secure its customers' safety. ${ }^{90}$ The plaintiff's injuries were held to be the direct result of that failure. ${ }^{91}$

The legal principles which underpin this liability were elucidated in another case arising from Louisiana, in which a patron of a motel was in the process of checking in and was assaulted by another resident who had been acting in a suspicious manner. ${ }^{92}$ The Court noted that the least standard of care applying to the operators of the motel was as follows:

[T]he duty to protect business patrons does not extend to the unforeseeable or unanticipated criminal acts of an independent third person. Only when the owner or management of a business has knowledge, or can be imputed with knowledge, of a third person's intended criminal conduct which is about to occur, and which is within the power of the owner or management to protect against, does such a duty of care towards a guest arise. ${ }^{93}$

It would be difficult to imagine a statement of law more clearly reflecting the foreseeability/capacity analysis. The principle's enduring effect is reflected in a 1997 decision by the Supreme Court of Washington. In Nivens v. 7-11 Hoagy's Corner, the patron of a convenience store was assaulted by one or more youths who were gathered outside the store. ${ }^{94}$ The plaintiff alleged negligence by the operators of the store in failing to hire security staff. $^{95}$ The court explained that:

[t]he common law recognizes an exception to the general rule, however; there is a duty to protect another from the

87. Borne v. Bourg, 327 So. 2 d 607, 609 (La. Ct. App. 1976).

88. Id.

89. Id.

90. Id. at 610 .

91. Id.

92. Davenport v. Nixon, 434 So. 2d 1203, 1204 (La. Ct. App. 1983).

93. Id. at 1205.

94. Nivens, 943 P. $2 d$ at 287-88.

95. Id. at 288. 
criminal acts of third persons when a special relationship is present. A special relationship exists between a business and its invitees so that the business has a duty to take reasonable steps to prevent harm to its invitees from the acts of third parties on the premises, if such acts involve imminent criminal conduct or reasonably foreseeable criminal behaviour. ${ }^{96}$

Although the classification of business and invitee as a "special relationship" must involve a certain amount of question-begging, the requirement for knowledge and the requirement of 'reasonable' steps are indistinguishable from the principles in Davenport $v$. Nixon. ${ }^{97}$

\section{GAPS AND WHAT LIES BENEATH}

The exceptions to imposition of liability lend support to the existence of an underlying jurisprudential norm of "foreseeability + capacity = duty." 98 Two exceptions are particularly enlightening: in Australia, the general absence of liability of government agencies for criminal offending; in the United States, the "fireman's rule."

\section{A. The State and the Offenders}

The common law world outside the United States has taken its bearings on the liability of state agencies for criminal offenders from English law. The general rule is set out in Hill v. Chief Constable of West Yorkshire. ${ }^{99}$ The plaintiff sought compensation for the death of a victim of the "Yorkshire Ripper." 100 The matter was eventually appealed to the House of Lords. Lord Keith reviewed the case of Dorset Yacht Co. Ltd. v. Home Office ${ }^{101}$ and stated:

The alleged negligence of the police consists in a failure to discover [the wanted criminal's] identity. But if there is no general duty of care owed to individual members of the public by the responsible authorities to prevent the escape of a known criminal or to recapture him, there cannot

96. Id. at 293-94.

97. See Davenport, 434 So. $2 \mathrm{~d}$ at 1205.

98. See supra Part II.A-B.

99. Hill v. Chief Constable of West Yorkshire, [1989] 1 A.C. 53 (H.L.) (appeal taken from Eng.).

100. Id. at 64 .

101. Dorset Yacht Co. Ltd. v. Home Office, [1970] A.C. 1004 (H.L.) (appeal taken from Eng.). 
reasonably be imposed upon any police force a duty of care similarly owed to identify or apprehend an unknown one. ${ }^{102}$

The decision has been considered a number of times in both Britain and the other common law countries. The British had some minor concerns regarding the decision in $2005^{103}$ but the decision has since been firmly upheld. ${ }^{104}$ It has been followed in New Zealand. ${ }^{105}$ On the other hand, the Supreme Court of Canada has doubted its correctness, ${ }^{106}$ and the Supreme Court of Appeal of South Africa did not follow it. ${ }^{107}$ There has been no authoritative ruling on the applicability of Hill's case in Australia, ${ }^{108}$ but the indications are that the courts will follow it. The High Court of Australia ${ }^{109}$ and the Master of the Supreme Court of Tasmania ${ }^{110}$ have viewed this as good law.

The exclusion of a duty of care is explained by the relationship of the type of claim posited to the foreseeability/capacity rule. In a case of the type raised in Hill v. Chief Constable of West Yorkshire, the concept of foreseeability itself is probably inapplicable. Foreseeability would lose much of its analytical utility if liability for negligence by a state agency could be imposed. In other words, if harm to a significant percentage of society was foreseeable and it generated a duty to each member of that society, the bounds of the relevant agency's duties would potentially be limitless. Moreover, the capacity of a police force to discharge its duty might well be very questionable; arresting, charging or convicting an offender does not guarantee the police will not cause harm. An offender might escape from a prison post conviction, ${ }^{111}$ or from the police custody while awaiting charges, ${ }^{112}$ or be convicted and then mistakenly released too early. ${ }^{113}$ Moreover, operational and societal realities may make effective or successful policing impossible. Reviewing a book on the present state of

102. Hill, [1989] 1 A.C. at 62 (Lord Brandon of Oakbrook, Lord Oliver of Aylmerton, and Lord Goff of Chieveley concurring).

103. Brooks v. Comm'r of Police for the Metropolis [2005] UKHL 24 (H.L.) 493-94 (ף 3)(appeal taken from Eng.) (Lord Bingham of Cornhill, Lord Nicholls of Birkenhead).

104. Smith v. Chief Constable of Sussex Police, [2008] EWCA (Civ) 39 (Eng.).

105. Hobson v. Att'y-Gen. [2005] 2 NZLR 220 (HC) 239.

106. Hill v. Hamilton-Wentworth Reg'l Police Servs. Bd. (2007) 285 D.L.R. 4th 620 , 642-44 (ף142) (S.C.C.) (McLahlin, CJC., Binnie, LeBel, Deschamps, Fish and Abella, JJ. concurring).

107. Van Eeden v. Minister of Safety \& Sec. 2002 (1) SA 389 (A) at 399-400 (\$20) (S. Afr.).

108. New South Wales v Spearpoint [2009] NSWCA 233, $\uparrow 9$ (Austl.).

109. Sullivan v Moody [2001] 207 CLR 562, 581 (Austl.).

110. Courtney v Tasmania [2001] TASSC 83 (Sup. Ct. Tas) (Austl.).

111. Thorne \& Rowe v Western Australia [1964] WAR 147 (Sup. Ct. WA) (Austl.).

112. Van Eeden, [2003] (1) SA 389 (A) (S. Afr.).

113. Lv South Australia (Unreported, Dist. Ct. SA, 6 Aug. 2004) (Austl.). 
Britain's criminal justice system, Theodore Dalrymple comments bitterly:

The police ... are like a nearly defeated occupying colonial force that, while mayhem reigns everywhere else, has retreated to safe enclaves, there to shuffle paper and produce bogus information to propitiate their political masters. Their first line of defense is to refuse to record half the crime that comes to their attention, which itself is less than half the crime committed. Then they refuse to investigate recorded crime, or to arrest the culprits even when it is easy to do so and the evidence against them is overwhelming, because the prosecuting authorities will either decline to prosecute, or else the resultant sentence will be so trivial as to make the whole procedure (at least 19 forms to fill in after a single arrest) pointless.

In any case, the authorities want the police to use a sanction known as the caution-a mere verbal warning. Indeed, . . . the Home Office even reprimanded the West Midlands Police Force for bringing too many apprehended offenders to court, instead of merely giving them a caution. In the official version, only minor crimes are dealt with in this fashion: but . . . in the year 2000 alone, 600 cases of robbery, 4,300 cases of car theft, 6,600 offenses of burglary, 13,400 offenses against public order, 35,400 cases of violence against the person, and 67,600 cases of other kinds of theft were dealt with in this fashion-in effect, letting these 127,900 offenders off scot-free. ${ }^{114}$

In such circumstances the House of Lords' reluctance to overlay police operational decisions with a duty of care to the public at large seems to reflect the reality that, even where a crime might be foreseeable, the police may have little or no capacity to prevent it. These concerns, the almost unlimited foreseeability of harm from offending and questionable capacity, have been reflected in Australian jurisprudence in this area.

In Peat $v$ Lin, the plaintiff alleged that three off-duty police officers were negligent in failing to prevent a breach of the peace in which he was assaulted. ${ }^{15}$ Justice Atkinson accepted that the police did not have a blanket immunity from suit in negligence. ${ }^{116}$ However, he concluded that, "[t]o

114. Theodore Dalrymple, Real Crime, Fake Justice, CITY JouRnal, Summer 2006, available at http://www.city-journal.org/16_3_oh_to_be.html.

115. Peat v Lin [2005] 1 Qd R 40 (Sup. Ct. Qld) (Austl.).

116. Id. at $47-48$. 
impose upon an ill-equipped, unarmed, off-duty police officer a duty in tort to act to endeavor to prevent a possible or potential breach of the peace in this situation would be to impose too onerous a duty on such a person."117

His Honor went to some lengths to explain his reluctance to impose liability:

Any duty owed was to the public at large and there are strong policy reasons to deny the existence of a duty of care to the plaintiff as an individual. As I have observed, the common law has shown a marked reluctance to impose liability on police officers in this situation. One reason is because the class of persons to whom the duty is owed is too indeterminate; where, one may ask rhetorically, would it stop: is a duty owed to staff and people inside the nightclub; patrons outside the nightclub and passers by; pedestrians and other drivers whom the potential offender might encounter; persons who live with, or a family member of, the potential offender whom he might assault? Secondly, police officers owe a number of duties and the satisfaction of the duty towards or interests of one member of the public may interfere with duties owed to other members of the public or, more importantly, the public at large; the duty is owed to the public at large and not to an individual. Thirdly, the court is reluctant to intervene in what are primarily operational decisions as to what reaction is appropriate in the given situation. Further, to impose a duty in a case such as this is to impermissibly interfere in the operational decisions of the police service. It is a matter for the administration of the police service when to roster police on duty and when to roster them off-duty. If police were expected to be ever vigilant to prevent breaches of the peace whilst off-duty, as if they were on duty, this would be likely to impact on rostering decisions and procedural instructions given to police officers as to how they may or may not spend their leisure hours. ${ }^{118}$

In $X v$ South Australia (No. 3), the Full Court of the Supreme Court of South Australia considered the duty of a Parole Board. ${ }^{119}$ The claim concerned a plaintiff who was sexually assaulted by a paroled offender and

118. Id.

119. X v South Australia [2007] 97 SASR 180 (Sup. Ct. SA) (Austl.) (Full Court). 
who brought proceedings based on the board's alleged negligence. Justice Duggan noted, inter alia, the Board's limited capacity to monitor or restrain parolees along with the evidence available to the board, and concluded that it did not at any time owe a duty of care to the plaintiff. ${ }^{120}$ Justice Debelle reviewed the statutory scheme applying to the Board, the potentially counterproductive effect of imposing a duty of care, the limited powers of the Board, and the very large number of people vulnerable to harm if the Board erred in its tasks. He concluded that:

[T]he Parole Board is not subject to a duty of care generally to the community. Such a duty of care would be inconsistent with its function and the statutory scheme. The Board would be exposed to an indeterminate liability in circumstances where it has quite limited control over a person released on licence. ${ }^{121}$

His Honor proceeded to consider whether a duty of care might exist if the Board had information suggesting the possibility of harm to an individual or group of individuals. He noted that the Board is a body with a statutory discretion and concluded that:

it is inconsistent with the exercise of a statutory discretion to impose a duty of care on a decision made within the ambit of that statutory discretion. To impose a duty of care upon the exercise by the Board of its discretion as to how to deal with a report concerning a person released on licence would be to cut directly across the principle of public law relating to the grounds on which the exercise of a discretion may be reviewed. For this reason, the Board is not subject to a duty of care when it makes a decision concerning information even where there is a specific risk of harm to a personal class of persons. Although the Board will in those circumstances be subject to a duty of care to act in the sense of considering whether to act or not, and might be liable for a failure to consider the portion ... it will not be subject to a duty of care if it has acted and in the exercise of its discretion made a decision. In short, once it has discharged its statutory duty and in the exercise of its discretion has decided whether or not to act, the Board might be subject to public law remedies but is not subject 
to a duty of care. ${ }^{122}$

Leave to appeal the question of the existence of a duty of care to the High Court of Australia in this case was refused. ${ }^{123}$

The decision in Peat $v$ Lin $^{124}$ could have been justified in the absence of policy considerations by His Honor's references to the burdensomeness of requiring an off-duty police officer to take steps to prevent a breach of the peace when manifestly ill-equipped to do so. That is, where the defendant was clearly without capacity to protect the plaintiff. Capacity (or lack thereof) to exercise control over parolees was cited as a reason for denying a duty of care in $X v$ State of South Australia (No. 3). ${ }^{125}$ In both Peat and $X$, foreseeability also loomed as a concern for identifying a duty of care. The policy concerns cited in Peat reflect a lack of meaningful foreseeability of harm standard: to require an off-duty police officer to take reasonable care to protect every person with whom an aggressive drunk might come in contact would expand the range of foreseeability to the point where the concept becomes meaningless. A similar concern with indeterminate liability is also evident in $X v$ State of South Australia (No. 3): if foreseeability were to have a role in establishing the bounds of a public body's responsibility, the public law remedies referred to by Justice Debelle would become effectively meaningless. ${ }^{126}$

In the case of Thorne and Rowe v. State of Western Australia, the plaintiffs alleged negligence by prison authorities in allowing Thorne to escape who then proceeded to assault the plaintiffs (including the offender's wife). ${ }^{127}$ The offender had previously threatened Mrs. Thorne with a firearm, was arrested, and found to be carrying a dagger, a length of string, and a bottle of sulphuric acid. ${ }^{128} \mathrm{He}$ stated to the arresting officer that he had intended to tie his wife up and throw the acid in her eyes. ${ }^{129}$ Thorne pled guilty to a number of charges and was sentenced to twelve months imprisonment. ${ }^{130}$ After sentencing, he stated to a police officer: "this will not stop me; I will get out and fix her." ${ }^{131}$ The officer passed this warning to the prison wardens. About two weeks later, Thorne did indeed escape and went to his wife's dwelling and attacked her and her partner (Rowe)

122. Id. at 234-35 ( $\$ 196)$.

123. $X v$ South Australia (Unreported, High Ct. of Austl., 16 Nov. 2007) (Gleeson, CJ. \& Heydon, J.).

124. Peat $v$ Lin [2005] 1 Qd R 40 (Sup. Ct. Qld) (Austl.).

125. $X$ [2007] 97 SASR 180.

126. Id.

127. Thorne \& Rowe v Western Australia [1964] WAR 147, 149 (Sup. Ct. WA) (Austl.).

128. Id. at 148 .

129. Id.

130. Id.

131. Id. 
with a tomahawk thus causing significant injuries. ${ }^{132}$ Justice Negus held that:

[A] mere breach of [the wardens'] duty to the Crown to keep prisoners in safe custody could not give the plaintiffs a right of action. The plaintiffs must establish they had a special duty to Mrs. Thorne and failed in that duty. The existence of such a special duty, assuming the facts of this case provide an exception to the general rule, that one man is under no duty of controlling another to prevent his doing damage to a third ... depends on their knowledge that Thorne had a propensity or intention or was likely to attack his wife. They knew of the threat, but it cannot be inferred from the fact of the threat having been made that Thorne had that propensity and intention. He must have had many opportunities of attacking and injuring his wife. There was no evidence that he had ever done more than poke a pistol in her back: but he did not press the trigger--though he could have done so. ${ }^{133}$

With the greatest of respect to His Honor, in light of the history, it is difficult to imagine what more proof by Thorne could have been offered for a propensity, intention, or likelihood to attack his wife. ${ }^{134}$

Liability was found to be arguable in Swan $v$ South Australia, in which the plaintiff was an infant who suffered sexual abuse at the hands of a pedophile then on parole. ${ }^{135}$ The Parole Board and parole officers of the Department of Correctional Services had been aware of allegations that the offender was in breach of his parole conditions but made inadequate efforts to follow up. Justice Bollen (Justice Mohr agreeing) found that the defendant's knowledge of a breach of a parole condition that could cause

132. Id. at 150 .

133. Id. at 151 .

134. Cf. Williams v. New York, 127 N.E.2d 545 (N.Y. 1955) (William Kennedy, an inmate of a prison farm in New York State, escaped due to the negligence of prison officers. $\mathrm{He}$ armed himself and subsequently hijacked a truck driven by one Albert Williams. The fear engendered by Kennedy caused Williams to suffer a brain hemorrhage and die. Proceedings were brought by the widow of the deceased. The claim was dismissed on the grounds that the injury was not foreseeable: "[a]s to Williams, the State's claimed carelessness was 'negligence in the air' or 'in the abstract,' ... and was not joined to his death by the element of foreseeability. His death therefore may not be included within the class of consequences of the State's negligence for which it must answer in damages.") $I d$. at 550 . One notes that the Court reviewed Kennedy's criminal record and (if asked) would probably have had difficulty finding the foreseeability of injury required by Modbury Triangle Shopping Ctr. Pty. Ltd. v Anzil [2000] 205 CLR 254, 267 (Austl.).

135. Swan v South Australia [1994] 62 SASR 532 (Sup. Ct. SA) (Austl.) (Full Court). 
harm to foreseeable persons created a relationship of proximity between the plaintiff and the defendant. ${ }^{136}$ Foreseeability and causation were also established by the facts of this case. Therefore, a duty of care arose for the defendant to take reasonable steps to protect the plaintiff once the defendant, through his officers, knew or had reason to suspect failure to comply with the conditions of parole would cause harm. ${ }^{137}$ Unfortunately, this decision is now questionable following the High Court of Australia's rejection of "proximity" as a test for the existence of a duty of care. ${ }^{138}$ However, at least one commentator seems to hold the factors establishing a duty of care as doing so even after proximity is barred as an analytical concept. ${ }^{139}$ This suggests liability in this case was established by foreseeability alone, although one can assume the capacity of the appropriate state agencies to protect the plaintiff's wellbeing in the given circumstances.

Foreseeability was the critical factor in Thorne and Rowe $v$ State of Western Australia ${ }^{140}$ and Swan v State of South Australia. ${ }^{141}$ In Thorne the cause of action was rejected on the grounds that the harm caused was not foreseeable. While one could argue that Thorne was wrongly decided, the line of reasoning supporting the outcome squarely reflects the foreseeability/capacity analysis. ${ }^{142}$ Swan represents the other end of the outcome spectrum: perhaps because of the Court's use of proximity, the decision found liability based on foreseeable harm to an identifiable person. ${ }^{143}$

\section{B. Bad Things Happen to Firemen: The American Exception}

The "fireman's rule" in American common law can be explained by the acceptance of the foreseeability/capacity analysis as the basis for imposing a duty of care. The fireman's rule has been explained as follows:

It is quite generally agreed the owner or occupier is not liable to a paid fireman for negligence with respect to the creation of a fire.... The rationale of the prevailing rule is sometimes stated in terms of "assumption of risk," used

136. Id. ๆ 33(Bollen \& Mohr, JJ.).

137. Id.

138. Sullivan v Moody, [2001] 207 CLR 562, 578-79 (Austl.).

139. Martin Cuerden, He Should Have Been in Prison, 72 PRECEDENT 28, 31-32 (2008). See also Imbree v McNeilly [2008] 236 CLR 510, 660, (Austl.) (Gummow, Hayne and Kiefel, JJ.) (Gleeson, CJ. \& Crennan, J. concurring).

140. Thorne \& Rowe v Western Australia [1964] WAR 147, 149 (Sup. Ct. WA) (Austl.).

141. Swan, 62 SASR, ๆ 33.

142. Thorne \& Rowe, WAR at 149.

143. Swan, 62 SASR, ๆ 33. Cf. Peat v Lin [2005] I Qd R 40, ๆ19 (Sup. Ct. Qld) (Austl.). 
doubtless in the so-called "primary" sense of the term and meaning that the defendant did not breach a duty owed, rather than that the fireman was guilty of contributory fault in responding to his public duty. . . . Stated affirmatively, what is meant is that it is the fireman's business to deal with that very hazard and hence, perhaps by analogy to the contractor engaged as an expert to remedy dangerous situations, he cannot complain of negligence in the creation of the very occasion for his engagement. In terms of duty, it may be said there is none owed the fireman to exercise care so as not to require the special services for which he is trained and paid. ${ }^{144}$

This principle has been accepted as applying equally to the police as to the fireman. ${ }^{145}$

The rule tends to be justified in policy terms. The Supreme Court of New Jersey has explained that:

[I]n the final analysis the policy decision is that it would be too burdensome to charge all who carelessly cause or fail to prevent fires with the injuries suffered by the expert retained with public funds to deal with those inevitable, although negligently created, occurrences. Hence, for that risk, the fireman should receive appropriate compensation from the public he serves, both in pay which reflects the hazard and in workmen's compensation benefits for the consequences of the inherent risks of the calling. ${ }^{146}$

Denying the equal application of the rule would lead to some rather confusing pleadings before the courts. In one matter, where a police officer was injured after trying to quell a disturbance in a bar and duly sought compensation from the (inter alia) bar owner, the court said:

Plaintiff's contention puts a bartender in the position of being responsible to patrons for injuries he does not prevent by, among other means, calling the police and to the police if he calls them and one is injured. We therefore hold that the ambit of protection owed by the bartender does not

144. Krauth v. Geller, 157 A.2d 129, 130-31 (N.J. 1960).

145. Holdsworth v. Renegades of Louisiana Inc., 516 So. 2d 1299, 1302 (La. Ct. App. 1987). Cf. Orth v. Cole, 955 P.2d 47, 49 (Ariz. Ct. App. 1998) (holding that the rule does not apply in non-emergency, non-rescue situations.).

146. Krauth, 157 A.2d at 130-31. 
extend to the policeman acting as such. ${ }^{147}$

A later Court's comment on that case gives an insight into how the fireman's rule reflects the foreseeability/capacity analysis such that being justified in policy terms alone would render the principle open to rejection. ${ }^{148}$ Commenting on Weaver v. O'Banion, the Louisiana Court of Appeal explained:

In effect, the court refused to burden a business proprietor with a similar liability standard first to patrons on the premises and second to those summoned in their professional capacity to aid the patrons in time of danger. This policy encourages a proprietor to call for professional help and discourages dangerous attempts at self-help. ${ }^{149}$

Courts are indeed generally unwilling to encourage self-help. As Justice (of Court of the Appeal) Edmund Davies noted that, "the law regards with the deepest suspicion any remedies of self-help, and permits those remedies to be resorted to only in very special circumstances." reluctance to encourage voluntary election as to what legal obligations one considers binding: one recalls Viscount Haldane's ringing statement that "by the law of this country no man can be restrained of his liberty without authority in law," could be maintained if it was agreed upon. ${ }^{152}$ This legal trend against selfhelp options might also be part of the approach by governmental authorities: in an age where the legitimacy of the law making process is contested, ${ }^{153}$ it is hard to imagine a more corrosive tendency than to encourage the legal process to be bypassed by self-help measures. The Courts have reciprocated their reluctance to outsource policing functions to

147. Weaver v. O'Banion, 359 So. 2d 706, 708 (La. Ct. App. 978).

148. E.g., Club Italia (Geelong) Inc v Ritchie [2001] 3 VR 437, \{ף $50-51$ (Vic Ct. App.) (Austl.) (noting that the rule had also been rejected in Britain. Ogwo v. Taylor [1988] 1 A.C. 431(H.L.) 448-49 (appeal taken from Eng.)).

149. Solis v. Civic Ctr. Site Dev. Co. Inc., 385 So. 2d 1229, 1232 (La. Ct. App. 1980).

150. Southwark London Borough Council v. Williams, [1971] $1 \mathrm{Ch} 734,745$ (Eng.).

151. Herd v. Weardale Steel, Coal \& Coke Co. Ltd., [1915] A.C. 67 (H.L.) 71 (Eng).

152. Id. at 72-73 (Viscount Haldane LC); id. at 75 (Lord Shaw of Dunfermline); id. at 77 78 (Lord Moulton). Intriguingly, this case can also be read as an instance of the parallel tortious concept of voluntary assumption of risk. 28 HALSBURY's LAWS OF ENGLAND 82 (3d ed. 1959).

153. See Randy E. Barnett, Foreword: Guns, Militias and Oklahoma City, 62 TENN. L. REv. 443, 457-58 (1995); see also Allen Buchanan, Federalism, Secession, and the Morality of Inclusion, 37 ARIZ. L. REv. 53, 55 (1995) and James M. Buchanan, Federalism and Individual Sovereignty, 15 CATO J. 259, 265 (1995); but see Leslie Green, Un-American Liberalism: Raz's 'Morality of Freedom', 38 U. TORONTO L.J. 317, 318-19 (1988). 
the public. ${ }^{154}$

The fireman's rule, by reflecting a policy against self help, can be justified as a reflection of the foreseeability/capacity analysis. It can be fairly assumed that harm befalling a police officer in the course of preventing a crime will almost always be foreseeable to a person responsible for the offender. However, a lack of capacity must be assumed by the court to sustain a policy against self-help. If it is presumed that a person will obey the law at least in the absence of actual evidence they will not do so, ${ }^{155}$ and if they are capable of preventing a crime by their own efforts, it is not logical to presume that there would be any societal harm flowing from self-help measures. The rule can therefore be justified when interpreted to discourage self-help by its consistency with the underlying foreseeability/capacity analysis.

\section{SO FAR, SO GOOD. SO WHAT?}

The foreseeability/capacity analysis provides a means of deconstructing the common law on liability for injuries caused by third parties. Working lawyers, however, would be entitled to respond by asking what practical value this analytical tool adds. An answer is suggested by a somewhat unusual case of liability for a criminal act: the curious English matter of Christopher Meah. ${ }^{156}$

Christopher Meah was a passenger in a car driven by Kenneth McCreamer on August 9, 1978. Both men had been drinking. McCreamer lost control of the vehicle. In the resulting accident, Meah suffered serious head injuries including brain damage, which caused a significant personality change in him. ${ }^{157} \mathrm{He}$ subsequently sexually assaulted and wounded three women, resulting in a sentence of life imprisonment. ${ }^{158} \mathrm{He}$ sued McCreamer for his injuries and for the sentence of imprisonment to which he was subject. ${ }^{159}$ Following the accident, McCreamer disappeared

154. Nivens, 943 P.2d at 293 ("Nivens ... [argued that] a business generally owes a duty to provide security personnel to prevent criminal behavior on the business premises. We decline to find such a duty. To do so would unfairly shift the responsibility for policing, and the attendant costs, from government to the private sector.'); $c f$. Modbury Triangle Shopping Ctr. Pty. Ltd. v Anzil [2000] 205 CLR 254, 292-93 (Austl.) (Hayne, J.).

155. See Gollan v Nugent [1988] 166 CLR 18, 48 (Austl.) (appeal taken from New South Wales) (Deane, Dawson, Toohey \& Gaudron, JJ.) "The law does not penalize intention. On the contrary, it recognizes a locus poenitentiae and assumes that the opportunity for repentance may be exercised." Id.

156. Meah v. McCreamer (No 1), [1985] 1 All E.R. 367 (Q.B.) (Eng.); W v. Meah, [1986] 1 All E.R. 935 (Q.B.) (Eng.); Meah v. McCreamer (No 2), [1986] 1 All E.R. 943 (Q.B.) (Eng.).

157. Meah v. McCreamer (No. 1) [1985] 1 All ER 367 (Queens Bench Div.).

158. Id.

159. Id. 
and the solicitors and barristers acting in his name were instructed by his insurers to make the matter a slight variation from the theme of claims for criminal acts of third parties. Justice Woolf approached the matter on the basis that:

[I]f it can be shown on the balance of probabilities that but for the accident and the injuries the plaintiff suffered as a result, he would not have committed the crimes referred to in the amended statement of claim and, therefore, would not be now serving a sentence of life imprisonment, it was not argued on behalf of the defendant that the plaintiff is not entitled to be compensated for that and, indeed, entitled to receive substantial damages in respect of that matter. ${ }^{160}$

His Honor concluded that but for the head injury the plaintiff would not have committed the relevant attacks and "that to some extent he is not to be blamed ... because but for an unfortunate road accident he would not have been turned into the sort of individual who could commit those attacks." $"$ Justice Woolf proceeded to award compensation for both the injuries and the imprisonment. ${ }^{162}$

Later, two of Meah's victims successfully sued him in proceedings which were presided over by Justice Woolf. ${ }^{163}$ Meah then sued McCreamer and his insurers to recover the amounts awarded to the two women. ${ }^{164}$ Justice Woolf this time held that

if an action had been brought by the two victims against the driver, in respect of the sexual attacks which were inflicted on them by the plaintiff, the courts would have held that that damage was remote, and that no duty was owed by the driver to the victims of the plaintiff's sexual assaults. ${ }^{165}$

He proceeded to find that the liability in damages was not foreseeable to the driver or his insurers. ${ }^{166}$

His Honor's rulings in the two actions against McCreamer are not easy to reconcile: if the chain of events leading to criminal liability was

160. Id. at 371 .

161. Id. at 382 .

162. Id. at 383 .

163. W \& D v. Meah [1986] 1 All ER 935 (Queens Bench Div.).

164. Meah v. McCreamer (No. 2) [1986] 1 All ER 943 (Queens Bench Div.).

165. Id. at 950 (In the proceedings by the victims " $D$ " did in fact issue proceedings against both Meah and McCreamer but did not proceed at trial against the latter. $W \& D$, [1986] 1 All ER at 935-936.).

166. Meah (No 2), 1 All ER at 950. 
foreseeable and compensable, it is difficult to see why the events leading to civil liability were not. A legal practitioner advising a client as to his or her prospects of successful litigation would struggle to draw guidance from the two cases. However, assessing the two judgments' compatibility with the foreseeability/capacity analysis could accurately shape the advice given. This would reveal that while McCreamer was arguably able to prevent the eventual assaults (by driving more safely on the night in question), they were not in fact foreseeable (as was in fact found in Meah v. McCreamer (No 2)). The first decision critically failed to recognize that Meah retained the capacity to appreciate the crime involved in the assaults and the (unexercised) capacity to resist temptation. ${ }^{167}$ That he retained this ability should logically have reduced the scope of things, which Mr McCreamer should have foreseen, to the point where no duty could be found. As a result, it would be better for the practitioner to base their advice on the judgment in the second action against McCreamer and to advise a plaintiff against litigation. ${ }^{168}$

\section{CONCLUSION}

Australian and American common law on liability for criminal acts of third parties can be explained as an articulation of an underlying jurisprudential foreseeability/capacity analysis. This basic principle is reflected in the now leading Australian case of Modbury Triangle Shopping Centre Pt.y Ltd. $v$ Anzil and its effects have been worked through in subsequent cases. The same principle supports the imposition of liability in "special relationship" cases and the decision in Club Italia (Geelong) Inc. $v$ Ritchie gives some indication of the extent to which the principle may allow liability to be imposed on third parties. The foreseeability/capacity analysis is even more clearly reflected in the American cases on premises liability and in the exemption from liability available to government instrumentalities in Australia.

The value of the foreseeability/capacity analysis in considering third party criminal liability lies in its capacity to render uneven legal doctrine coherent. The "fireman's rule" of American law may well be justifiable in policy terms; however it can more respectably be said to reflect a defendant's presumptive lack of capacity to prevent harm which must, ultimately, be the justification for the courts' policy of discouraging selfhelp measures. Further, it offers a means for preferring one line of authority

167. See Harold Luntz, Assessment of Damages for Personal InJury and Death 208-209 (4th ed. 2002).

168. Such a decision would to some extent be validated by the subsequent disapproval of Meah v McCreamer (No. 1) on the grounds that issues of legal policy were not considered at the hearing. The Meah v McCreamer (No. 1) decision may now be regarded as discredited. E.g., Clunis v. Camden \& Islington Health Auth., [1998] Q.B. 978, 989-990 (Eng.). 
over another according to how closely the cases reflect the underlying norm (as in the matter of Mr. Meah). In a field where the injured party will almost always have been the victim of harsh, arbitrary and high-handed conduct by an offender, a significant step to restoring their confidence in the world around him or her should be the provision of legal advice which is clear, sound, and consistent with established doctrine. Recognition of the foreseeability/capacity analysis as an analytical tool goes some way towards meeting this need. 